\title{
Infant respiratory symptoms in relation to mite allergen exposure
}

\author{
R.T. van Strien*, A.P. Verhoeff**, J.H. van Wijnen**, G. Doekes*, \\ G. de Meer*, B. Brunekreef *
}

Infant respiratory symptoms in relation to mite allergen exposure. R.T. van Strien, A.P. Verhoeff, J.H. van Wijnen, G. Doekes, G. de Meer, B. Brunekreef. CERS Journals Ltd 1996.

ABSTRACT: The relationship between the Dermatophagoides pteronyssinus (Der $p$ ) I content of house dust and the respiratory symptoms reported for young infants was studied.

One hundred and four infants, aged 3-15 months, were selected during JulySeptember 1993 through the Dutch postnatal health care service, using a short screening questionnaire to identify mothers with respiratory allergy to house dust and/or pets. Fortyeight were selected from this group of mothers ("high risk" infants) and 56 infants were selected when neither of the parents reported allergy or chronic respiratory symptoms ("low risk" infants). All homes were visited in October 1993. Dust samples were collected from the infant's mattress and from other places in the home, and the Der $p$ I content was measured in dust extracts. The results indicate that on more than half of the mattresses, the Der $p$ I level was over $2,000 \mathrm{ng} \cdot \mathrm{g}^{-1}$, the level suggested to be associated with an increased risk of sensitization. Information on respiratory symptoms ("wheeze" and "prolonged cough") experienced since birth was obtained by questionnaire from one of the parents on the dust sampling day.

The occurrence of respiratory symptoms in the infants appeared to be positively related to the Der $p$ I concentration of the dust.

Although no objective measurements of respiratory symptoms were available, the results of this study suggest that exposure to mite allergen in early life may lead to respiratory symptoms that are suggestive of airway obstruction in the first year of life. Eur Respir J., 1996, 9, 926-931.

\author{
*Dept of Epidemiology and Public Health, \\ University of Wageningen, Wageningen, \\ The Netherlands. **Dept of Environmental \\ Medicine, Municipal Health Department \\ of Amsterdam, Amsterdam, The Netherlands. \\ Correspondence: B. Brunekreef \\ Dept of Epidemiology and Public Health \\ University of Wageningen \\ P.O. Box 238 \\ 6700 AE Wageningen \\ The Netherlands \\ Keywords: Allergens \\ allergy \\ dust mites \\ infants \\ respiratory symptoms
}

Received: March 161995

Accepted after revision January 101996

The study was supported by a grant from The Netherlands Asthma Foundation.
Several studies have suggested that allergen avoidance diminishes the severity of respiratory symptoms in sensitized asthmatic subjects [1-4]. There is also good evidence that exposure to mite allergens increases the risk of sensitization [5-6]. The results of these cross-sectional studies were also confirmed by the results of one prospective study, in which exposure at $1 \mathrm{yr}$ of age was found to be associated with sensitization and respiratory symptoms at $11 \mathrm{yrs}$ of age [7].

Children with asthma are more likely to have started experiencing lower respiratory illness (LRI) early in life than nonasthmatic children. However, many young children experience such illness at least intermittently, and only a certain proportion of infants with LRI will develop asthma at a later age [8-13]. LRI is associated mostly with viral infections [13]. In addition, genetic and environmental factors, e.g. atopy of parents and siblings and exposure to Environmental Tobacco Smoke (ETS), have been positively and independently associated with infant wheezing LRI [14-16].

In the avoidance study that is being conducted on the Isle of Wight, the group of children who are avoiding contact with allergens, food allergens as well as inhalable allergens, are sensitized less often at 2 yrs of age compared to a control group [17]. The prevalence of asthma, defined as three or more separate episodes of cough and wheeze, was significantly higher in the control group at $1 \mathrm{yr}$ of age and also at 2 yrs of age, but not significantly so $[17,18]$. In a cross-sectional Australian study, increased mattress dust Der $p$ I concentrations in 45 one months old infants [19].

In this study, respiratory symptoms (episodes of wheeze and/or cough) in 3-15 months old infants were studied in relation to the Der $p$ I concentration in house dust.

\section{Methods}

\section{Subjects}

A short screening questionnaire containing questions on respiratory allergies and respiratory symptoms, was distributed to parents of young infants. The parents were attending infant health centres in the west and central part of The Netherlands. Both biological parents were requested to complete the questionnaire. In July, August and September 1993, the health centres received 1,650 questionnaires, of which 648 were returned by the parents. 
Of these, 543 questionnaires fulfilled the following four conditions: 1) questionnaire returned before October 1st; 2) questionnaire answered completely; 3) information obtained from both biological parents; and 4) infant aged $3-15$ months on October 1st 1993. At the health centres, not all 1,650 questionnaires were actually given out to parents, and due to the organizational structure of the infant health care system, the total number of questionnaires handed out was unknown.

Of the 543 infants who met all criteria, 67 (12\%) had a mother who reported to have a doctor diagnosed and/or doctor treated allergy for "house dust" and/or pets ("atopic mother"). Fifty one parents in this group were randomly asked by telephone to participate in the study and all of them agreed. For 228 out of the 543 infants, neither parent reported any allergy or chronic respiratory symptoms ("nonatopic parents"). From this group, the parents of 58 infants, frequency matched according to month of birth, were randomly asked to participate and only two of them refused. Eventually, complete data were obtained for 48 infants with an atopic mother, and for 56 infants with nonatopic parents.

Homes of the selected infants were visited in October 1993 by two different investigators, blinded with respect to the atopic status of the parents of the infants. During this home visit, dust samples were taken for Der $p$ I concentration measurements, and one of the parents was interviewed on a variety of topics, related to the respiratory health status of the infant.

\section{Dust sampling and analysis}

Dust samples were taken from the living room floor, the parental bedroom floor, the infant's bedroom floor and the infant's mattress surface. Samples were taken according to guidelines proposed by a World Health Organization (WHO) workshop report [20] with some moderations. The exact sampling, storage and extraction procedures are described elsewhere [21]. The limit of detection of the enzyme-linked immunosorbent assay (ELISA) for Der $p$ I was $1 \mathrm{ng} \cdot \mathrm{mL}^{-1}$, and samples below the limit of detection were given the value of $0.7 \mathrm{ng} \cdot \mathrm{mL}^{-1}$.

\section{Questionnaire}

A detailed interview was held with one of the parents, at the day of the home visit, concerning a number of health characteristics of their infant. The following questions on infant respiratory symptoms were asked: 1) "Did your child ever wheeze?"; 2) "Did your child ever cough for prolonged periods?"; and 3) "Did you ever visit a physician with your child because of respiratory symptoms?" The questionnaire also contained questions on skin rash, atopic eczema as diagnosed by a physician, and food allergy or intolerance in the infant. Furthermore, information was obtained about known risk factors for childhood respiratory disease, e.g. smoking in the home, the presence of pets, and visits to infant day care centres.

\section{Statistical analysis}

Statistical analysis was performed on a VAX main frame computer using Statistical Analysis System (SAS) v.6.07 (SAS Institute Inc., Cary, NC, USA).
"Respiratory symptoms" were defined as a positive answer to the question on wheeze and/or the question on prolonged cough. The data on health characteristics of the infant were related to various factors, including the $\operatorname{Der} p$ I concentration in house dust. Initially, infants with nonatopic parents and the group of infants with an atopic mother were considered separately in the analyses; this was because differences in Der $p$ I concentrations in dust could potentially occur due to allergen avoidance measures already implemented by atopic parents, as suggested in an earlier study [6]. Another reason was the potential for responder bias; atopic mothers might report respiratory symptoms in their infants more readily than nonatopic parents. When performing pooled analyses for the whole group, using logistic regression analysis, atopy in the parents was always taken into account.

The Der $p$ I concentrations in dust from the mattress surface, the infant's bedroom floor, the parental bedroom floor and the living room floor were divided into two categories for each analysis. The cut-off concentrations were set at 1,000, 2,000 and 5,000 $\mathrm{ng} \cdot \mathrm{g}^{-1} \mathrm{dust}$. Also, the highest of all $\operatorname{Der} p$ I concentrations in one home was considered, using the same cut-off points.

Analysis was performed using frequency tables and Mantel Haenszel "odds ratios" in bivariate comparisons, and logistic regression in the multivariate analyses. Associations between health outcome and potential risk factors were expressed as "odds ratios", with their 95\% confidence intervals.

\section{Results}

Table 1 presents some characteristics of the study group, for infants of nonatopic parents and infants of atopic mothers separately. Among infants of atopic mothers, the proportion of boys is higher than among infants of nonatopic parents $\left(\chi^{2}=3.9 ; \mathrm{p}<0.05\right)$. Furthermore, infants of atopic mothers had on average a $236 \mathrm{~g}$ lower birth weight $(\mathrm{t}=2.2 ; \mathrm{p}<0.05)$. When this difference was adjusted for duration of pregnancy, which was also lower for

Table 1. - Characteristics of infants in study population

\begin{tabular}{|c|c|c|}
\hline & $\begin{array}{l}\text { Infants of } \\
\text { "nonatopic" } \\
\text { parents } \\
(\mathrm{n}=56)\end{array}$ & $\begin{array}{l}\text { Infants of } \\
\text { "atopic } \\
\text { mother" } \\
(\mathrm{n}=48)\end{array}$ \\
\hline Age months" & $8(4)$ & $8(3)$ \\
\hline Gender of infant $\%$ male & 41 & 60 \\
\hline Firstborn infant $\%$ & 32 & 31 \\
\hline Duration of pregnancy weeks & $40.0(1.3)$ & $39.5(1.9)$ \\
\hline Birth weight of infant $\mathrm{g}^{\#}$ & $3590(523)$ & $3354(553)$ \\
\hline Age of mother at birth $\leq 30 \mathrm{yrs} \%$ & 50 & 58 \\
\hline Age of father at birth $\leq 30$ yrs $\%$ & 23 & 33 \\
\hline $\begin{array}{l}\text { At least one parent with } \\
\text { higher education \% }\end{array}$ & 64 & 77 \\
\hline Sibling with atopic/allergic disease & 36 & 58 \\
\hline \multicolumn{3}{|l|}{ Presence of pets in the house $\%$} \\
\hline At present & 23 & 42 \\
\hline Ever, but not anymore & 36 & 23 \\
\hline Never & 41 & 35 \\
\hline Smoking in the house $\%$ & 48 & 42 \\
\hline Smoking by mother during pregnanc & y $\% 18$ & 17 \\
\hline Parent reported mould/damp in house & e $\% 54$ & 60 \\
\hline
\end{tabular}

\#: mean and SD in parenthesis. 
Table 2. - Health characteristics of the infant as reported by the parents

\begin{tabular}{lcc}
\hline & $\begin{array}{c}\text { Infants of } \\
\text { "nonatopic" } \\
\text { parents } \\
(\mathrm{n}=56)\end{array}$ & $\begin{array}{c}\text { Infants of } \\
\text { "atopic } \\
\text { mother" } \\
(\mathrm{n}=48)\end{array}$ \\
\hline $\begin{array}{l}\text { Hypersensitive to certain foods } \% \\
\text { Hospitalisation \% }\end{array}$ & 20 & 27 \\
$\begin{array}{l}\text { Frequent skin rash \% } \\
\text { Atopic eczema (as diagnosed }\end{array}$ & 13 & 15 \\
$\quad \begin{array}{l}\text { by physician) \% } \\
\text { Respiratory symptoms } \\
\text { (cough/wheeze) \% }\end{array}$ & 2 & $42^{*}$ \\
$\begin{array}{l}\text { Visit to physician } \\
\text { (respiratory problems) } \%\end{array}$ & 11 & $35^{*}$ \\
\hline
\end{tabular}

*: $\mathrm{p}<0.05\left(\chi^{2}\right.$-test $)$, compared to infants of nonatopic parents.

infants of atopic mothers, it became less pronounced and was no longer significant (difference $=156 \mathrm{~g} ; \mathrm{t}=1.6 ; \mathrm{p}=0.12$ ). Infants of atopic mothers had on average older parents, more siblings with atopic disease, and more pets in their homes.

Table 2 presents health characteristics of the infants, as reported by their parents. For 99 of the 104 infants, the mother was interviewed. For infants of atopic mothers, respiratory symptoms were reported much more frequently than for infants of nonatopic parents $\left(\chi^{2}=9.2 ; \mathrm{p}<0.01\right)$. Also, frequent skin rash was reported more often for infants of atopic mothers $\left(\chi^{2}=8.4 ; p<0.01\right)$. For five $(=10 \%)$ of the infants of atopic mothers but only one infant of nonatopic parents, atopic eczema was reported to have been diagnosed by a physician $\left(\chi^{2}=3.5 ; \mathrm{p}<0.1\right)$. Visits to a doctor because of respiratory problems were made more often with infants of atopic mothers than with infants of nonatopic parents. Atopic mothers who also reported physician diagnosed asthma did not report respiratory symptoms in their infants significantly more frequently than atopic, nonasthmatic mothers (39 and 34\%, respectively).

Table 3 shows the association between reports of respiratory symptoms (i.e. wheezing and/or prolonged cough) in the infants and several possible explanatory factors.
"Pets" refers to a feathery or furry pet being kept in the home at the time of the home visit, or that a pet had been kept in the home after the birth of the infant. Older infants were more likely to have had respiratory symptoms than younger infants, especially older infants of atopic mothers. None of the other factors that were investigated showed a clear relationship with respiratory symptoms in the infants.

Figures 1 and 2 show the proportion of infants (with nonatopic and atopic parents, respectively) with $\operatorname{Der} p$ I concentrations $<1,1-2,2-5$ and $>5 \mu \mathrm{g}^{\circ} \mathrm{g}^{-1}$ for the various locations. In $36 \%$ of the homes, the highest Der $p$ I concentration was found in dust from the parental bedroom floor, in $23 \%$ of the homes in dust from the living room floor, in $28 \%$ of the homes in infant mattress surface dust, and in $13 \%$ of the homes in dust from the infant's bedroom floor. A more detailed description of these results will be published separately [21].

Table 4 shows the unadjusted odds ratios for the relationship between infant respiratory symptoms and Der $p$ I for three different cut-off points $(1,000,2,000$ and $\left.5,000 \mathrm{ng} \cdot \mathrm{g}^{-1}\right)$ for the Der $p$ I concentration in dust from the various locations, and for the highest Der $p$ I concentration in the home. The odds ratios are shown separately for infants of nonatopic and atopic parents.

Table 5 shows "odds ratios" for all infants, using logistic regression analysis to adjust for atopy of the mother and age of the infant (in months). All infants were included in these analyses, because in the stratified analyses no evidence was found that atopy of the mother would act as an effect modifier. Atopy of the mother and age of the infant showed a strong relationship with respiratory symptoms in the infants throughout all analyses. The estimated odds ratios for Der $p$ I exposure were all above unity, but not statistically significant. Only when the highest Der $p$ I concentration in the home was considered, a cut-off point of $2,000 \mathrm{ng} \cdot \mathrm{g}^{-1}$ showed a statistically significant association with infant respiratory symptoms.

No relationship was found between frequent skin rash, without reports of food allergy or intolerance, and the Der $p$ I concentration in the various locations in the home.

Table 3. - Odds ratios for the association between infant respiratory symptoms (frequent cough and/or wheeze) and various risk factors

\begin{tabular}{|c|c|c|c|}
\hline Risk factors & $\begin{array}{c}\text { Infants of } \\
\text { "nonatopic" parents } \\
(\mathrm{n}=50)^{\#} \\
(\mathrm{n}=6)^{\ddagger}\end{array}$ & $\begin{array}{r}\text { Inf } \\
\text { "atopi } \\
(\mathrm{n} \\
(\mathrm{r}\end{array}$ & $\begin{array}{l}\text { ants of } \\
\text { c" parents } \\
(=31)^{\#} \\
n=17)^{\ddagger}\end{array}$ \\
\hline $\begin{array}{l}\text { Age (odds ratio expressed } \\
\text { per month) }\end{array}$ & $1.1(0.9-1.4)$ & 1.3 & $(1.1-1.6)^{*}$ \\
\hline Gender male & $0.7(0.1-4.2)$ & 1.3 & $(0.4-4.6)$ \\
\hline Firstborn infant & $0.4(0.1-3.4)$ & 0.3 & $(0.1-1.4)$ \\
\hline Maternal age at birth $\leq 30$ yrs & 1.0 & 1.0 & $(0.3-3.3)$ \\
\hline Paternal age at birth $\leq 30$ yrs & $4.0(0.8-21.2)$ & 0.8 & $(0.2-2.8)$ \\
\hline At least one parent with higher education & $1.1(0.2-6.9)$ & 1.0 & $(0.2-3.9)$ \\
\hline Sibling with atopic/allergic disease & $1.6(0.3-9.8)$ & 2.4 & $(0.7-8.0)$ \\
\hline Contact with pets & $0.3(0.1-1.7)$ & 1.5 & $(0.4-5.5)$ \\
\hline Smoking in the house & $1.6(0.3-10.6)$ & 1.4 & $(0.4-4.7)$ \\
\hline Smoking by mother during pregnancy & $0.9(0.1-9.0)$ & 1.1 & $(0.2-5.5)$ \\
\hline Mould or damp spots in house & $1.9(0.3-11.0)$ & 2.0 & $(0.6-7.0)$ \\
\hline
\end{tabular}

Values are presented as odds ratio, and $95 \%$ confidence interval in parenthesis. \#: no respiratory symptoms in infants; *: respiratory symptoms in infants. *: $\mathrm{p}<0.05$, compared to absence of risk factor. 


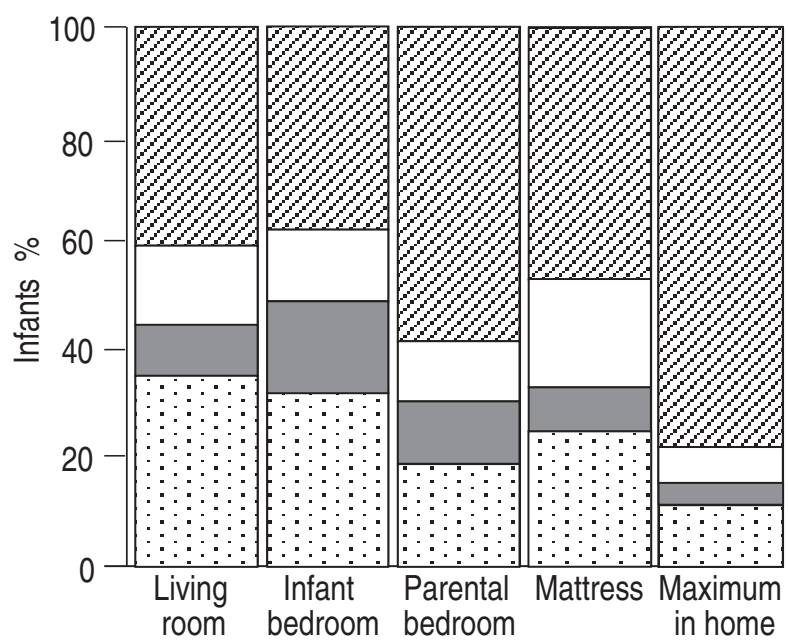

Fig. 1. - Percentages of infants of "nonatopic" parents with Der $p$ I concentrations $<1,1-2,2-5$ and $>5 \mu \mathrm{g} \cdot \mathrm{g}^{-1}$ in dust from the various locations. $\square:<1 \mu \mathrm{g} \cdot \mathrm{g}^{-1} ; \square: 1-2 \mu \mathrm{g} \cdot \mathrm{g}^{-1} ; \square: 2-5 \mu \mathrm{g} \cdot \mathrm{g}^{-1} ; \square$ : $>5 \mu \mathrm{g} \cdot \mathrm{g}^{-1}$.

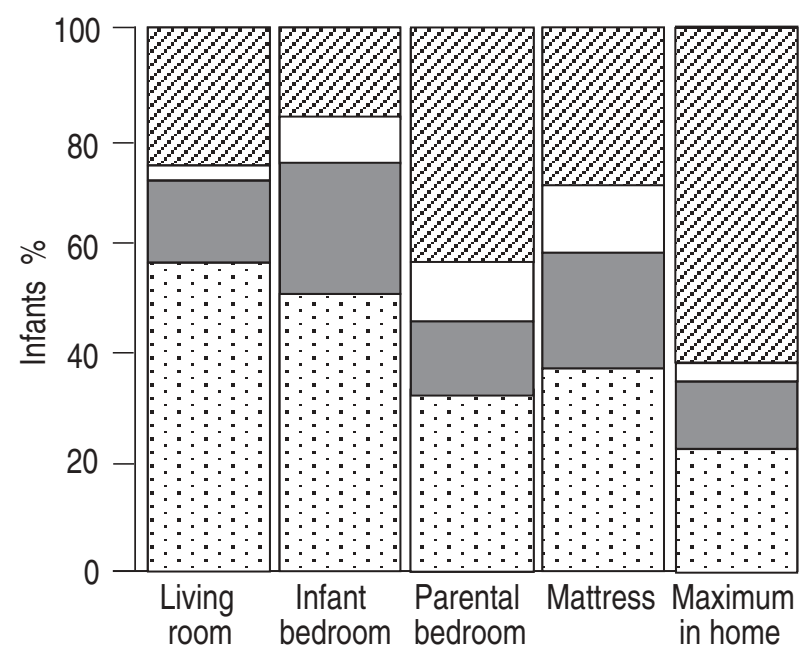

Fig. 2. - Percentages of infants of "atopic" parents with Der $p$ I concentrations $<1,1-2,2-5$ and $>5 \mu \mathrm{g} \cdot \mathrm{g}^{-1}$ in dust from the various locations. $\square:<1 \mu \mathrm{g} \cdot \mathrm{g}^{-1} ; \square: 1-2 \mu \mathrm{g} \cdot \mathrm{g}^{-1} ; \square: 2-5 \mu \mathrm{g} \cdot \mathrm{g}^{-1} ; \square:>5$ $\mu \mathrm{g} \cdot \mathrm{g}^{-1}$

\section{Discussion}

This study shows that after adjustment for age and parental atopy, Der $p$ I in house dust was associated with the frequency of parental reports of wheeze and/or frequent cough in 3-15 month old infants. The relationship was most prominent when infants exposed to more than $2,000 \mathrm{ng} \cdot \mathrm{g}^{-1}$ were compared to infants exposed to less than $2,000 \mathrm{ng} \cdot \mathrm{g}^{-1}$.

Confidence intervals of most odds ratios were wide, due to the relatively small number of infants in the study and to the relatively small number of infants with low or negligible exposure to Der $p$ I. In future studies, a group of infants avoiding exposure to mite allergens might be needed to enlarge the group of infants with low or negligible levels of exposure.

When all odds ratios presented in tables 4 and 5 are considered, it is clear that almost all were higher than unity. The separate analyses in table 5 are, of course, not independent but were executed in an attempt to find out which exposure variable and which cut-off point provided the most meaningful results. This is clearly of interest for evaluation of exposure levels in future studies, and for the design of new studies. when decisions need to be made with respect to where to sample house dust for determination of mite allergen levels.

Asthma diagnosis among atopic mothers was not associated with a difference in reports of respiratory symptoms in the infants, indicating that among atopic mothers, responder bias with regard to respiratory symptoms in their infants did not seem to occur.

Results similar to ours were found in a study by O'KEEFFE et al. [19] who showed a positive association between airway responsiveness to histamine and Der $p$ I concentrations in mattress dust in 45 one month old infants. In various studies, a positive association was found between respiratory symptoms as well as skin test reactivity and bronchial responsiveness in adults [22]. In the Isle of Wight allergen avoidance study, six infants of a control group of 62 "high risk" infants showed a positive skin-prick test after $1 \mathrm{yr}$ of follow-up and 16 showed a positive skin-prick test to common allergens after 2 yrs of follow-up. In the prophylactic group $(n=58)$ of this study the number of infants with a positive skin-prick test were only 2 and 3 , respectively $[17,18,23]$.

Table 4. - Crude "odds ratios" for the relationship between Der $p$ I exposure and respiratory symptoms in infants with atopic mothers and infants with nonatopic parents

\begin{tabular}{lccc}
\hline & \multicolumn{3}{c}{ Der $p$ I concentration $\mathrm{ng} \cdot \mathrm{g}^{-1}$} \\
\cline { 2 - 4 } & \multicolumn{1}{c}{$>1000$} & $>2000$ & $>5000$ \\
\hline Infants of "nonatopic" parents & & & \\
Mattress surface & $5.3(0.3-100.5)^{\#}$ & $2.7(0.3-23.4)$ & $1.1(0.2-6.3)$ \\
Infant bedroom floor & $2.6(0.3-23.0)$ & $2.1(0.4-12.4)$ & $3.9(0.7-21.8)$ \\
Parental bedroom floor & $3.6(0.2-70.0)^{\#}$ & $0.9(0.1-5.3)$ & $1.5(0.2-9.0)$ \\
Living room floor & $3.0(0.4-25.9)$ & $4.6(0.6-36.8)$ & $3.3(0.6-18.9)$ \\
Maximum in the home & $1.9(0.1-38.7)$ & $2.7(0.1-51.9)^{\#}$ & $1.5(0.2-13.9)$ \\
Infants of "atopic" mother & & & \\
Mattress surface & $1.2(0.3-4.0)$ & $1.2(0.4-4.1)$ & $1.0(0.3-3.8)$ \\
Infant bedroom floor & $2.8(0.8-9.4)$ & $1.4(0.4-5.3)$ & $2.0(0.4-9.3)$ \\
Parental bedroom floor & $3.1(0.7-12.9)$ & $1.8(0.5-6.3)$ & $2.4(0.7-8.5)$ \\
Living room floor & $0.6(0.2-2.2)$ & $0.4(0.1-1.8)$ & $0.5(0.1-2.2)$ \\
Maximum in the home & $3.1(0.6-15.7)$ & $3.8(1.0-15.6)^{* *}$ & $2.0(0.6-7.0)$ \\
\hline
\end{tabular}

Values are presented as odds ratio, and 95\% confidence interval in parenthesis. \#: Logit estimation of odds ratio, no unexposed infants with respiratory symptoms. **: $\mathrm{p}<0.10$, compared to Der $p$ I concentration below cut-off value. 
Table 5. - Odds ratios for the relationship between Der $p$ I exposure and respiratory symptoms in infants, adjusted for maternal atopy and age of the child

\begin{tabular}{lccc}
\hline & \multicolumn{3}{c}{ Der $p$ I concentration $\mathrm{ng} \cdot \mathrm{g} \cdot^{-1}$} \\
\cline { 2 - 4 } & \multicolumn{1}{c}{$>1000$} & $>2000$ & $>5000$ \\
\hline Mattress surface & $1.5(0.5-4.9)$ & $1.5(0.5-4.4)$ & $1.0(0.3-3.1)$ \\
Infant bedroom floor & $2.3(0.8-7.2)$ & $1.5(0.5-4.5)$ & $2.3(0.7-7.7)$ \\
Parental bedroom floor & $3.1(0.8-12.9)$ & $1.2(0.4-3.6)$ & $1.9(0.6-5.4)$ \\
Living room floor & $1.0(0.4-2.8)$ & $1.2(0.4-3.6)$ & $1.2(0.4-3.7)$ \\
Maximum in the home & $3.7(0.7-20.2)$ & $4.8(1.1-21.1)^{*}$ & $1.9(0.6-6.3)$ \\
\hline
\end{tabular}

Values are presented as odds ratio, and 95\% confidence interval in parenthesis. *: $\mathrm{p}<0.05$, compared to Der $p$ I concentration below cut-off value.

Viral respiratory infections could not be assessed in this questionnaire study. These could also have had their influence on reports of respiratory symptoms $[13,24]$. It is not clear, however, that the occurrence of viral infections would be related to Der $p$ I exposure, and we have no information to decide whether confounding by viral infections could have occurred.

Levels of Der $p$ I concentrations in dust samples collected for this study did not differ very much from samples from corresponding locations collected in a previous study [25], and are also quite similar to concentrations in dust samples collected in climatically similar areas by other research groups $[5,7,26,27]$. When figures from Sweden are considered [28, 29], it is seen that already at the prevailing concentrations that were found in Sweden (in general lower than 2,000 $\mathrm{ng} \cdot \mathrm{g}^{-1}$ ) sensitization can occur. In our study, Der $p$ I concentrations were higher in dust from the homes of infants of nonatopic parents, compared to concentrations in dust from the homes of infants of atopic mothers. This indicates that atopic parents take allergen avoidance measures more frequently than nonatopic parents.

With the exception of age of the children and atopy of the mother, other potential risk factors for infant respiratory symptoms, such as gender of the infant, maternal and paternal age at birth, parental education level, sibling atopy, presence of or contact with pets, passive smoking, maternal smoking during pregnancy and damp/mould spots, were not significantly related to reported infant respiratory symptoms.

In conclusion, the results of this study suggest an association between early infant respiratory symptoms and high $\operatorname{Der} p$ I concentrations in the home.

\section{References}

1. Sarsfield JK, Gowland G, Toy R, Norman ALE. Mitesensitive asthma of childhood: trial of avoidance measures. Arch Dis Child 1974; 49: 716-721.

2. Burr ML, St Leger AS, Neale E. Anti-mite measures in mite-sensitive asthma, a controlled trial. Lancet 1976; 322: 333-335.

3. Korsgaard J. Preventive measures in mite asthma. Allergy 1983; 38: 93-102.

4. Walshaw MJ, Evans CC. Allergen avoidance in house dust mite sensitive adult asthma. $Q J$ Med 1986; 226 : 199-215.

5. Lau S, Falkenhorst G, Weber A, et al. High mite allergen exposure increases the risk of sensitization in atopic children and young adults. J Allergy Clin Immunol 1989; 84: 718-725.
6. Verhoeff AP, van Strien RT, van Wijnen JH, Brunekreef B. House dust mite allergen (Der $p$ I) and respiratory symptoms in children: a case-control study. Clin Exp Allergy 1994; 24: 1061-1069.

7. Sporik R, Holgate ST, Platts-Mills TAE, Cogswell JJ. Exposure to house dust mite allergen (Der $p$ I) and the development of asthma in childhood. $N$ Engl $\mathrm{J}$ Med 1990; 323: 502-507.

8. Strope GL, Stewart PW, Henderson FW, Ivins SS, Stedman HC, Henry MM. Lung function in school-age children who had mild lower respiratory illnesses in early childhood. Am Rev Respir Dis 1991; 144: 655-662.

9. Henderson FW, Stewart PW, Burchinal MB, et al. Respiratory allergy and the relationship between lower respiratory illness and subsequent lung function. Am Rev Respir Dis 1992; 145: 183-190.

10. Helms P. Editorial: wheezing infants. Clin Exp Allergy 1994; 24: 97-99.

11. Sherman CB, Tosteson TD, Tager IB, Speizer FE, Weiss ST. Early childhood predictors of asthma. Am J Epidemiol 1990; 132: 83-95.

12. Martinez FD, Wright AL, Taussig LM, Holberg CJ, Halonen M, Morgan MJ. Asthma and wheezing in the first six years of life. $N$ Engl J Med 1995; 332: 133 138.

13. Wilson NM. The significance of early wheezing. Clin Exp Allergy 1994; 24: 522-529.

14. Tager IB, Hanrahan JP, Tosteson TD, et al. Lung function, pre- and postnatal smoke exposure, and wheezing in the first year of life. Am Rev Respir Dis 1993; 147: 811-817.

15. Martinez FD, Wright AL, Holberg CJ, Morgan WJ, Taussig LM. Maternal age as a risk factor for wheezing lower respiratory illnesses in the first year of life. Am J Epidemiol 1992; 136: 1258-1268.

16. Young S, Le Souëf PN, Geelhoed GC, et al. The influence of family history of asthma and parental smoking on airway responsiveness in early infancy. $N$ Engl $J$ Med 1991; 324: 1168-1173.

17. Hide DW, Matthews S, Matthews L, Stevens M. Effect of allergen avoidance in infancy on allergic manifestations at age two years. J Allergy Clin Immunol 1994; 93: 842-846.

18. Arshad SH, Matthews S, Gant C, Hide DW. Effect of allergen avoidance on development of allergic disorders in infancy. Lancet 1992; 339: 1493-1497.

19. O'Keeffe PT, Young S, Arnott J, et al. Association between Der $p$ I exposure and airway responsiveness in early infancy. Eur Respir J 1994; 7 (Suppl. 18): 29s (Abstract).

20. Platts-Mills TAE, De Weck AL. Dust mite allergens and asthma: a worldwide problem. J Allergy Clin Immunol 1989; 83: 416-427.

21. van Strien RT, Verhoeff AP, van Wijnen JH, Doekes G, 
de Meer G, Brunekreef B. Der $p$ I concentrations in mattress surface and floor dust collected from infant bedrooms. Clin Exp Allergy 1995; 25: 1184-1189.

22. Rijcken B, Schouten JP, Mensinga IT, Weiss ST, de Vries K, van der Lende R. Factors associated with bronchial responsiveness to histamine in a population sample of adults. Am Rev Respir Dis 1993; 147: 1447-1453.

23. Arshad SH, Stevens M, Hide DW. The effect of genetic and environmental factors on the prevalence of allergic disorders at the age of two years. Clin Exp Allergy 1993; 23: 504-511.

24. Holberg CJ, Wright AL, Martinez FD, Ray CG, Taussig LM, Lebowitz MD. Risk factors for respiratory syncytial virus-associated lower respiratory illnesses in the first year of life. Am J Epidemiol 1991; 133: 1135-1151.

25. van Strien RT, Verhoeff AP, Brunekreef B, van Wijnen JH. Mite antigen in house dust: relationship with different housing characteristics in The Netherlands. Clin Exp Allergy 1994; 24: 843-853.

26. Ehnert B, Lau-Schadendorf S, Weber A, Schulz J, Wahn U. Sensitization to indoor allergens in infants at age 1 . J Allergy Clin Immunol 1993; 91: A732 (Abstract).

27. Kuehr J, Frischer T, Karmaus W, Meinert R, Barth R. Natural variation in mite antigen density in house dust and relationship to residential factors. Clin Exp Allergy 1994; 24: 229-237.

28. Wickman M, Nordvall SL, Pershagen G, Sundell J, Schwartz B. House dust mite sensitization in children and residential characteristics in a temperate region. $J$ Allergy Clin Immunol 1991; 88: 89-95.

29. Munir AKM, Einarsson R, Kjellman N-IM, Björkstén B. Mite (Der p I, Der $f \mathrm{I})$ and cat $(F e l d \mathrm{I})$ allergens in the homes of babies with a family history of allergy. Allergy 1993; 48: 158-163. 